\title{
Memes de internet na Ecologia da Mídia: entre metáforas e teorias,
}

\author{
Herivelton Regiani ${ }^{1}$ \\ Viviane Borelli 2
}

\begin{abstract}
Resumo: O presente artigo busca articular o conceito de meme com a abordagem teórica da ecologia da mídia. Considera ambos, meme e ecologia da mídia, como metáforas, empréstimos da linguagem biológica ao contexto comunicacional. Porém a ecologia da mídia situa-se como metáfora de tal modo abrangente e profícua que se constitui em teoria, com o potencial de integrar outros conceitos de origem semelhante. É neste contexto que os memes de internet podem ser melhor compreendidos e tensionados. Este artigo descreve e analisa memes de internet sobre temáticas diversas e os situa nessa perspectiva ecológica.
\end{abstract}

Palavras-chave: memes; ecologia da mídia; teorias da comunicação.

\begin{abstract}
This article intends to comprehend the concept of meme in an integrated manner with the theoretical approach of media ecology. It considers both meme and media ecology as metaphors from the biological language to communication context. However the media ecology is a metaphor insomuch comprehensive and fruitful that it becomes in a theory, with potential to integrate other concepts of similar origin. The internet memes can be better understood in this context. This article describes some internet memes related to various topics and analyses them in this ecological perspective.
\end{abstract}

Keywords: memes; media ecology; communication theories.

\section{Introdução}

A utilização de metáforas é um recurso útil a diferentes propósitos, como sensibilizar para assuntos ou aspectos não vistos, facilitar a compreensão de conceitos demasiado abstratos, adornar o texto ou investi-lo de aspectos poéticos. Mas as metáforas também se prestam a auxiliar na construção do conhecimento, no desenho do raciocínio e na própria configuração das teorias. Por vezes, conceitos bem

${ }^{1}$ Mestrando do Programa de Pós-Graduação em Comunicação da UFSM. Professor na Universidade Luterana do Brasil, campus Santa Maria, RS. E- mail: heriveltonreg@gmail.com.

2 Professora do Programa de Pós-Graduação da Universidade Federal de Santa Maria. Doutora em Ciências da Comunicação pela Unisinos. E-mail: borelliviviane@gmail.com 
estabelecidos em um campo do conhecimento podem ser tomados como empréstimo por outros campos de forma a funcionarem como metáforas. É o que ocorre na apropriação de conceitos das Ciências Naturais pelas Ciências Humanas, frequentemente na tentativa de elucidar temas e situações diferentes, mas com relações e funções semelhantes.

Neste artigo3, exploraremos duas dessas metáforas tomadas das Ciências Naturais para as Ciências Humanas: os conceitos de meme e de ecologia da mídia. Compreendemos ambos, meme e ecologia da mídia, como empréstimos de uma linguagem biológica para o contexto da pesquisa em comunicação. Entretanto, cada um destes conceitos tem história e amplitude diferentes. Pela maneira como já se configurou em discurso acadêmico e em teoria no campo da Comunicação, a ecologia da mídia é aqui tomada como uma metáfora maior, que tem o potencial de abrigar outras metáforas da mesma espécie. Assim, pode acolher, dar sentido mais relevante e conferir maior potencial de operação ao conceito de meme. Apontaremos algumas das razões para tal entendimento. Primeiramente, retomaremos ambos os conceitos em sua origem, história e aplicações. Em seguida, exploraremos algumas possibilidades de estudo dos memes dentro da perspectiva ecológica, a partir da análise de memes de internet selecionados. Esta seleção seguiu como critério a maneira como esses memes tornaram-se fecundos, amplamente reconhecidos e adaptados a distintos ambientes comunicacionais.

\section{A metáfora ecológica}

De acordo com Scolari (2013a) a aplicação da metáfora ecológica ao estudo dos meios de comunicação surgiu a partir dos anos 1960. Em um contexto maior que incluía conceitos como os de Antropologia Ecológica e Ecologia Política é que vai surgir a Ecologia da Mídia. É comum atribuir a Marshal McLuhan a paternidade do termo, situando-o entre os diversos aforismos e jargões criados em suas apresentações e debates. Mas, segundo Scolari:

${ }^{3} \mathrm{O}$ artigo integra uma problemática maior desenvolvida como pesquisa de mestrado em desenvolvimento no Programa de Pós-Graduação em Comunicação, que analisa memes de internet e sua apropriação em páginas de humor religioso no Facebook. 
Marshall McLuhan empregou na época o conceito de ecologia da mídia em algumas conversas privadas; no entanto, foi Neil Postman quem em 1968 o utilizou pela primeira vez em público em uma conferência no Concílio Nacional de Professores de Inglês. Três anos mais tarde, Postman inaugurava o programa de Ecologia da Mídia na Universidade de Nova York (SCOLARI, 2013a, p.33, tradução nossa).

Assim como Postman, anteriormente Harold Innis, professor e orientador de McLuhan, já preconizava uma visão integradora dos meios, considerados em sua influência sobre o ambiente da sociedade. A metáfora tornou-se de tal modo frutífera que se constituiu em um campo conversacional, em programa de estudos, e passou a circular como discurso acadêmico para, posteriormente, configurar-se como uma importante teoria da comunicação, agregando e integrando outros conceitos e reflexões.

A metáfora ecológica aplicada à comunicação foi desenvolvida em paralelo ao movimento ecológico, que veio apontar para a interdependência entre as espécies e para a impossibilidade de vida humana isolada do cuidado com as demais formas de vida e com os ambientes que as sustém. Na teoria da comunicação, o termo ecologia4 foi tomado como marco integrador, de forma a "delimitar um campo científico determinado", agregando "diferentes componentes e processos da esfera tecno-sociocomunicacional” (SCOLARI, 2010, p.19, tradução nossa). Essa metáfora-teoria compreende a maneira como os meios e tecnologias de comunicação constituem ambientes, à medida que se integram aos elementos que já existem na cultura e se configuram como produções que modificam essa mesma cultura.

Em decorrência, a ecologia da mídia lança olhar sobre a relação que se estabelece, na evolução comunicacional, entre os meios novos e antigos; da mesma forma, sobre a relação entre os ambientes gerados pelas tecnologias e os sujeitos que as utilizam; e ainda, sobre a atuação dos meios e sujeitos no ecossistema maior que é a cultura. Os meios de comunicação, assim como os sujeitos, são moldados pela cultura e, ao mesmo tempo, a modificam. Cada meio atua na formação de um ambiente, um modo de perceber o mundo.

$4 \mathrm{Na}$ sua etimologia, a palavra ecologia já carrega o potencial de atuar como marco integrador, referindo-se às lógicas da casa, às lógicas que regem e integram os diferentes elementos do ambiente em que se vive. Ecologia, do grego óikov (óikos: casa ou, em sentido amplo, "ambiente") e logia (logia: razão, lógica, utilizado nas ciências como "estudo"). 
Portanto, a ecologia da mídia não se aplica somente a um meio ou a um conjunto determinado de tecnologias. Tem a pretensão e o potencial de abrigar diferentes conceitos e relações, possibilitando uma compreensão dinâmica da cultura em sua relação com a tecnologia e os sujeitos.

[...] trata-se de uma teorização expandida que abarca, segundo o teóricoenunciador escolhido, quase todos os aspectos dos processos de comunicação, desde as relações entre os meios e a economia até as transformações perceptivas e cognitivas que sofrem os sujeitos a partir de sua exposição às tecnologias da comunicação [...] sua reflexão começa com a transição da oralidade para a escrita e chega até nossos agitados dias de vida digital" (SCOLARI, 2010, p.18, tradução nossa).

Scolari (2013b) ainda ressalta que a metáfora ecológica pode ser aplicada à mídia de duas maneiras complementares: a mídia como ambiente e os meios como espécies que interagem entre si. No primeiro caso, como cada nova tecnologia gera ambientes, afetando as pessoas que as utilizam. No segundo, investiga-se como cada meio se insere em um ambiente maior, um ecossistema midiático, e o modo como se relaciona outras espécies.

É nesse contexto abrangente que observamos a possibilidade de que o conceito de meme seja melhor pensado e tensionado, como parte integrante ou como uma das espécies do ecossistema midiático, impactando sobre os ambientes e interagindo com as demais espécies. Exploraremos aqui, suscintamente, alguns dos conceitos construídos em torno do processo de reprodução dos memes na internet, evidenciando como esta dinâmica pode ser inserida no referencial da ecologia da mídia. Interessa-nos o que os memes trazem de novo ao ambiente comunicacional, e de que forma modificam esse ambiente. Igualmente, como interagem com as outras espécies midiáticas. E, por fim, o que faz com que sejam tão utilizados e apropriados pelas pessoas e grupos de interesse em seu fazer comunicacional. Para esta última questão, serão projetadas algumas hipóteses.

\section{A metáfora meme}

A palavra é uma simplificação de mimeme ${ }^{5}$, que une a ideia de memória à de gene. Meme pode ser definido como uma unidade cultural que se multiplica em um

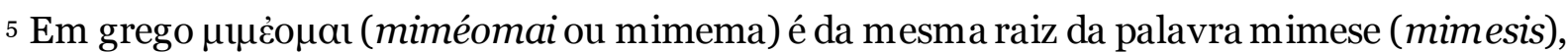
imitação.
} 
processo de cópia e imitação. Em sentido amplo, o conceito inclui falas, bordões, desenhos, comportamentos, ideias ou fragmentos de ideias, que são repetidas e - não sabemos bem porque - grudam na mente e se espalham rapidamente. De acordo com Recuero (2007, p.23) "o meme é um replicador, que se propaga através das pessoas, por imitação".

O termo não se aplica somente à internet, embora seja hoje o contexto no qual é amplamente utilizado ${ }^{6}$, mas é verificável em todos os contextos culturais que envolvem comunicação. Foi criado por Richard Dawkins no último capítulo de seu best seller "O Gene Egoísta", de 1976. O estudioso da teoria da evolução compreende meme como equivalente cultural ao gene biológico e o anuncia como um " novo tipo de replicador", bem mais recente que o gene, e que se prolifera em um outro ambiente:

O novo caldo é o caldo da cultura humana. Precisamos de um nome para o novo replicador, um substantivo que transmita a idéia de uma unidade de transmissão cultural, ou uma unidade de imitação. "Mimeme" provém de uma raiz grega adequada, mas quero um monossílabo que soe um pouco como "gene". Espero que meus amigos helenistas me perdoem se eu abreviar mimeme para meme. Se servir como consolo, pode-se, alternativamente, pensar que a palavra está relacionada a "memória", ou à palavra francesa même (DAWKINS, 2001, p.214).

Trata-se, então, de um conceito cunhado em um contexto biológico, mas formulado de forma a atender à compreensão de contextos mais amplos, como o da cultura. Dawkins (2001) chega a afirmar que, assim como os genes se propagam de corpo para corpo através de espermatozoides e óvulos, os memes se propagam de cérebro para cérebro por um processo de imitação.

Nesse contexto, há uma importante discussão quanto à abrangência do conceito de meme. Questiona-se até que ponto o conceito poderia ser estendido para uma explicação abrangente da dinâmica cultural. De acordo com Recuero (2011), Dawkins apresenta, em sua concepção de meme, a cultura inteira como produto da replicação de ideias. Nas palavras do autor, "quando você planta um meme fértil em minha mente, você literalmente parasita meu cérebro, transformando-o num veículo para a propagação do meme" (DAWKINS, 2001, p.215). A própria ideia Deus teria se

${ }^{6} \mathrm{Em}$ certo sentido, pode-se afirmar que o próprio termo meme tornou-se um meme, dada sua extensa utilização na internet sem que se pense sobre o que ele define ou que se conheça sua origem e significado. 
disseminado como um meme copiado por gerações sucessivas devido a seu "alto valor de sobrevivência", seu "poder infectante no ambiente produzido pela cultura humana" (DAWKINS, 2001, p.215).

Susan Blackmore é considerada pelo próprio Dawkins como quem levou mais longe o conceito, trabalhando-o de forma a propor uma teoria Memética, como modelo para explicação dos traços e comportamentos culturais. A autora criou um site para reunir artigos, estudos e outros materiais que ampliam e divulgam sua visão dessa teoria7. Em um desses artigos, The power of meme meme, afirma o que ela mesma considera audacioso:

Sem a teoria da evolução por seleção memética nada no mundo da mente faz muito sentido. Sem a memética você não pode responder a perguntas como "Por que eu não consigo tirar esse pensamento da minha mente? Por que eu decido escrever esse artigo e não aquele? Quem sou eu?" Sem a memética você pode apenas se sentar e apelar para um agente consciente imaginário (BLACKMORE, 1997, tradução nossa).

Levando a termo esse raciocínio, os memes seriam a base de tudo o que é produzido e reproduzido culturalmente, e atuariam quase que independentemente de nossa vontade, como replicadores que disputam por sobrevivência através de nós, se utilizam de nosso fazer e pensar com o fim de se reproduzir: memes autoreplicadores, tomando os seres humanos como vetores.

A crítica que se levanta é a de que, caso levada a termo, a memética poderia conduzir a um determinismo ultraevolucionista ou a um novo evolucionismo cultural. De acordo com Toledo:

Os memes seriam unidades de cultura transmitidas de pessoa a pessoa por imitação ou por outras formas de aprendizagem cultural. Desse modo, a transmissão dos memes seria semelhante o suficiente à transmissão de genes para utilizar os mesmos modelos. Basicamente o que se procura é fundamentar o estudo da cultura dentro do Pensamento Populacional já utilizado pela Biologia (TOLEDO, 2013, p.181).

A despeito da viabilidade epistemológica de uma teoria memética, que é o ponto discutido por Toledo (2013), o conceito de meme se consagrou como uma metáfora largamente utilizada, especialmente no contexto da propagação de

\footnotetext{
7 Disponível em: <http://www.susanblackmore.co.uk/memetics/index.htm>. Acesso em 20 Jun. 2015.
} 
conteúdo na internet. Aqui, tomamos o meme desta forma, como metáfora útil para a operação do conhecimento, e não como realidade determinante.

Entendemos que, no que concerne à comunicação, a metáfora pode ser melhor compreendida, problematizada e aplicada dentro de uma outra metáfora mais abrangente: a da ecologia da mídia. Isso evitaria, inclusive, um determinismo bilógico-evolucionista sobre a cultura, ou uma visão da propagação de memes como um processo simplesmente automático, alheio aos sujeitos.

Afinal, a perspectiva realmente ecológica ajuda a afastar determinismos, seja o biológico ou o tecnológico. Considera os meios e dispositivos tecnológicos em uma relação dinâmica com a cultura e com os sujeitos. Ou seja, "não se pode falar de determinismo tecnológico, senão de 'interação' homem-máquina, de interdependência ou ainda co-dependência mútua" (VIZER; CARVALHO, 2013, p.48, tradução nossa). Trata-se de uma perspectiva que deve considerar os meios e tecnologias como parte indissociável da cultura, dos processos de socialização e da história pessoal dos indivíduos.

\section{Possibilidades de estudo dos memes na perspectiva ecológica}

Incluir os memes no quadro conceitual da ecologia da mídia significa criar uma base de apoio para desvendar a maneira como eles convivem com outras espécies, o modo como copiam e adaptam características e o processo no qual são constantemente reformulados, por diferentes pessoas e grupos de interesse, para circularem em distintos ambientes e garantir sua reprodutibilidade. É possível analisar os memes de internet como tecnologia recente que reúne, recupera e reconfigura outras tecnologias, de maneira simples, porém altamente eficiente.

$\mathrm{Na}$ perspectiva ecológica de uma evolução das mídias, não há mera substituição ou extinção de espécies, mas convivência, interação e reformulação. É o que descreve a tétrade de McLuhan (1998). De acordo com a teoria, as realizações humanas em comunicação têm quatro efeitos ou propriedades: a) Extensão (ou Melhora): novos dispositivos tecnológicos são responsáveis por aperfeiçoar o meio ou parte dele, acentuando de maneira mais satisfatória alguma função humana; b) Obsolescência: os novos elementos tornam os antigos ultrapassados, como que anestesiando seus efeitos; c) Recuperação: mas a nova tecnologia ou novo meio 
sempre recupera algo do antigo, trazendo-o de volta de forma mais atualizada; d) Reversão: quando o novo se potencializa o bastante, ele se transforma em outra coisa, uma forma nova, seja complementar ou oposta. Esses efeitos descrevem um movimento ou evolução que tem impacto sobre todo o ambiente dos meios de comunicação. Devem ser considerados não de maneira estanque, como uma sucessão cronológica, podendo ocorrer até mesmo de forma simultânea (GHISLENI; BARICHELLO, 2013).

Os memes de internet também podem ser descritos segundo esses parâmetros. Em primeiro lugar, eles efetuam uma ampliação, estendendo as possibilidades de expressão e atuação dos indivíduos em um ambiente no qual já não há fronteiras tão delimitadas entre emissores e receptores, entre polos de emissão e polos de recepção. Qualquer pessoa com conhecimento dos usos e possibilidades criativas dos dispositivos digitais pode produzir, modificar e reproduzir memes a partir de textos, imagens ou vídeos já existentes, sem encontrar grandes barreiras técnicas ou econômicas.

Em segundo, memes também recuperam conteúdos, imagens, vídeos e textos gerados em outros meios, com traços característicos daqueles seus formatos, trazendo-os para o ambiente da internet. Pinturas antigas, fotos de peças publicitárias, personagens de filmes e séries e mesmo figuras importantes da história e da literatura são utilizadas, apropriadas, resignificadas.

Em terceiro lugar, à medida que os memes recuperam produções de outros dispositivos, também colocam em obsolescência os sentidos, os contextos e as lógicas de funcionamento originais. Apropriam-se apenas daquilo que interessa à sobrevivência nos novos contextos. Recuperam, mas fragmentam, retomam conferindo certa opacidade.

E, em quarto lugar, em seu processo de modificação ágil e quase sem limites, os memes acabam se revertendo em algo realmente novo no ambiente comunicacional. Agem, assim, como uma nova espécie que parasita as anteriores; que, a partir daquilo que retira das demais, constrói-se como algo simples e novo, que mais facilmente se propaga nos novos ambientes. 
Ainda nesse olhar sobre a propagação, é possível observar nos memes, em maior ou menor intensidade, três características apontadas por Dawkins (2007): longevidade, fecundidade e fidelidade das cópias. De acordo com Recuero (2007, p.3), essas características advêm da perspectiva darwinista, em que "as espécies eram vistas como produtos de um processo evolutivo baseado em três elementos fundamentais: mutação (ou variação), hereditariedade (ou retenção), e seleção natural”.

Essas características, acrescidas de uma quarta, são utilizadas por Recuero (2007) como critérios para construir uma taxonomia dos memes de internet. A autora chega, a partir delas, às seguintes categorias de classificação: fidelidade, longevidade e fecundidade. Acrescenta, ainda, uma quarta categoria, o alcance, para observar a relação entre os espaços nos quais os memes se propagam em redes sociais na internet.

A categoria fidelidade se refere a em que medida os memes preservam seus elementos constitutivos mesmo sendo reproduzidos em diferentes ambientes. Segundo esta, os memes podem ser classificados como replicadores (aqueles que se propagam com reduzida variação), metamórficos (que são completamente alterados ao serem copiados) ou miméticos (apesar de sofrerem mutações e recombinações, sua estrutura permanece basicamente a mesma).

Em uma relação com o conceito biológico de hereditariedade, avalia-se a longevidade dos memes. Ou seja, alguns se mostram persistentes (permanecem circulando por longo tempo), enquanto outros são voláteis (se propagam rapidamente, mas logo são esquecidos ou se modificam tanto que acabam se transformando em outro meme).

Quanto à fecundidade, os memes podem se propagar bastante a ponto de se tornar epidêmicos, ou ser apenas fecundos, espalhando-se por alguns espaços. Já quanto à variável alcance, memes podem se estabelecer como locais, circulando em uma determinada "vizinhança", ou seja, um conjunto de blogs ou páginas conectadas entre si, ou se estenderem de modo global.

Além dessa tipologia, que leva em conta o modo como os memes se proliferam na internet, os memes ainda podem ser classificados segundo seu formato. Assim, 
Souza (2014) os diferencia em dois grupos: a) expressões meméticas: falas e textos verbais que se disseminam em frases, áudios, vídeos e outros suportes; b) imagens meméticas: se reproduzem em forma de desenhos, cartuns e fotomontagens. Ainda poderíamos destacar videomemes como uma terceira categoria, para incluir os chamados "vídeos virais".

Para ilustrar a compreensão dos memes de internet na perspectiva da Ecologia da Mídia, destacamos aqui um tipo específico de imagens meméticas. São imagens sobrepostas por um texto verbal, de maneira a constituírem um todo unificado, um texto híbrido e que são como discursos, pois formam um corpo significante (VERÓN, 2005). Optamos por nomear esses conjuntos discursivos como memes imagéticos porque constituem uma matéria significante.

Esses memes imagéticos também são conhecidos como "memes de Facebook" por causa de sua propagação nesta rede social, embora sejam muito usados em blogs, fotologs e outras plataformas. Sua fecundidade e seu alcance são tão grandes que existem sites geradores de memes. São páginas que se oferecem como lugar de compartilhamento e, ao mesmo tempo, como ferramentas que possibilitam que qualquer pessoa insira ou modifique o texto em imagens prontas, para assim utilizálas em outros contextos ${ }^{8}$.

Trazemos, em seguida, variações de dois memes imagéticos conhecidos (Figuras 1 a 6). É possível, nesses exemplos, observar como imagem e texto formam um conjunto discursivo de tal maneira unificado que, modificando-se o componente verbal, toda a unidade discursiva se modifica. Igualmente, verificar a maneira simples e, por isso, poderosa, em que os memes estendem as possibilidades de comunicação, efetuando a recuperação de uma imagem anterior e, deixando em suspenso ou em obsolescência seu funcionamento original, a sua reversão em algo novo, para sobrevivência e proliferação em um novo ambiente.

Primeiramente, vejamos o meme conhecido como Willy Wonka Irônico (Figuras 1 a 3). Este meme utiliza a imagem da personagem de Gene Wilder no filme "A fantástica fábrica de chocolate" (Dirigido por Mel Stuart, 1971) em referências de

8 Exemplo é a página Meme Generator. Disponível em: <www.imgflip.com > acesso em 15 jun. 2015. 
humor. Na página Meme Center, que também funciona como um gerador de memes, a configuração da imagem em meme se dá com o acréscimo das seguintes sentenças: "Você julga os outros com frequência? "; "Conte-me então o quão perfeito você é" (Figura 1). A mesma imagem, replicada com diferentes frases, mas com referências do mesmo tipo irônico, é encontrada em diversos contextos, tornando difícil, senão impossível, rastrear onde o meme surgiu pela primeira vez. Esse processo de disseminação de discursos produzidos no contexto da ambiência digital remete também à problemática da circulação, que segundo Braga (2012) é difusa, contínua e segue fluxos sempre adiante.

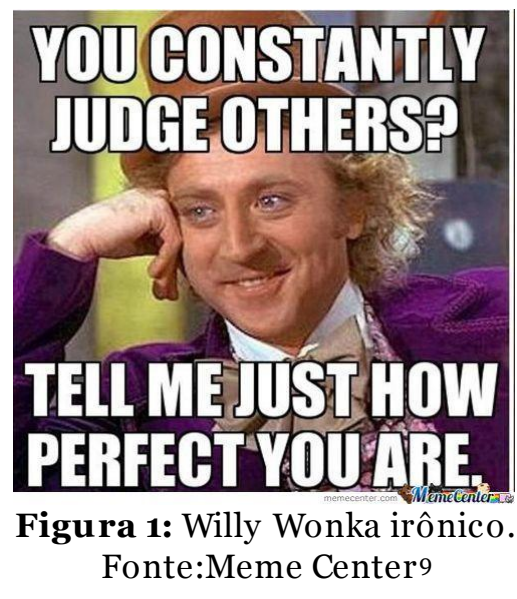

Em seguida, podemos ver o mesmo meme utilizado em outro contexto. Neste caso, no blog Le UFPR (Figura 2). Ainda mantendo o tom irônico, enaltece o ingresso na Universidade Tecnológica Federal do Paraná através do Exame Nacional do Ensino Médio (ENEM), em contraposição a ter que pagar a mensalidade em uma universidade privada, a Pontifícia Universidade Católica (PUC).

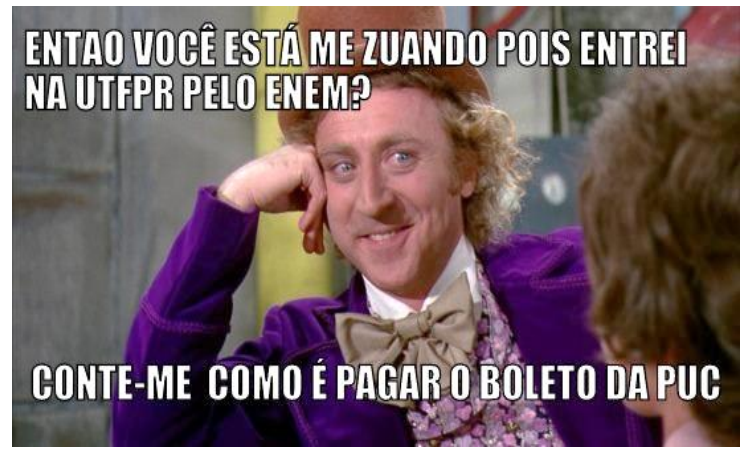

Figura 2: Willy Wonka irônico.

${ }_{9}$ Disponível em: <www.memecenter.com/search/willy\%20wonka> Acesso em 30 out. 2014. 
Fonte: Blog Le UTFPR ${ }^{10}$

Finalmente, o meme é readaptado em uma página de humor religioso chamada "Gospel e Nerd". Naquele contexto, refere-se a jovens cristãos que, ironicamente, são adictos de um jogo eletrônico chamado Diablo (Figura 3). O conjunto discursivo satiriza o fato de haver cansaço quando se trata de orar na madrugada, mas não para jogar a versão recém-lançada do game.

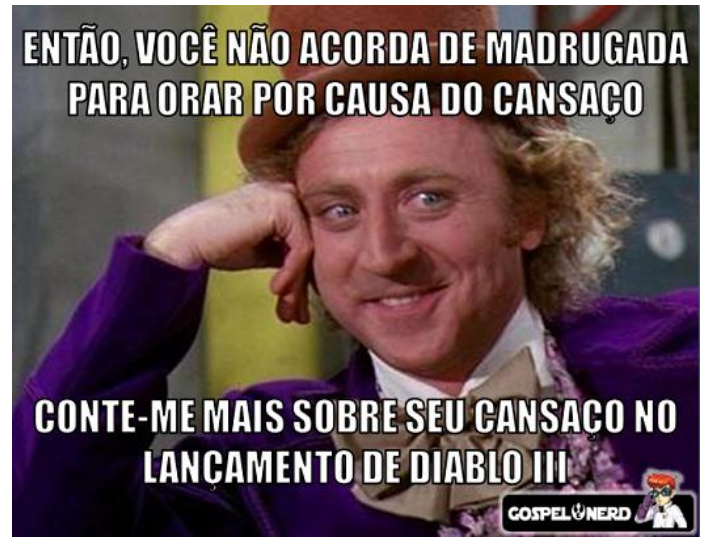

Figura 3: Willy Wonka irônico. Fonte: Blog Gospel e Nerd ${ }^{11}$

Note-se como, nos três casos citados, não há grande variação na imagem, a não ser pelo recorte e enquadramento ou pela inserção da marca característica da página em que é reproduzida. A mudança se dá na construção discursiva e na apropriação para um ambiente diferente, de acordo com a intenção dos sujeitos em seus contextos culturais específicos, apontando também para o modo como a geração e replicação de memes alcança distintas dimensões da experiência humana, distintos campos sociais (RODRIGUES, 1999).

Utilizando a classificação de Recuero, podemos enquadrar o meme Willy Wonka Irônico no tipo mimético. "A essência do meme está na personalização, mantendo a essência e a ordem estabelecidas. Daí o nome mimético, pois são memes que mantêm a estrutura, mas adaptam-se ao espaço onde estão sendo divulgados" (RECUERO, 2011, p. 126). Ainda seguindo a classificação da autora, trata-se de um

\footnotetext{
${ }_{10}$ Disponível em: <www.leutfpr.blogspot.com.br/2012/04/le-willy-wonka.html> Acesso em 30 out. 2014.

${ }^{11}$ Disponível em: <www.gospelenerd.com.br/2012/o5/willy-wonka-ataca-novamente.html> Acesso em 30 out. 2014.
} 
meme persistente quanto à longevidade, pois permanece se replicando por muito tempo. Quanto à fecundidade, temos este como um meme epidêmico, pois se difundiu rapidamente no Facebook, em blogs e por outras plataformas. Além disso, a apropriação em contextos temáticos e culturais tão diferenciados evidencia se tratar de um meme do tipo global.

Outro exemplo de meme imagético, desta vez, brasileiro na origem, é aquele apelidado de "Chico Buarque da Onda". Na composição, utiliza como base a capa do primeiro álbum do compositor Chico Buarque de Holanda, de 1966 (Figura 4). A capa original é modificada nas diferentes versões, invertendo posições, alterando cores e, especialmente, o texto verbal eleito para compor cada discurso específico.

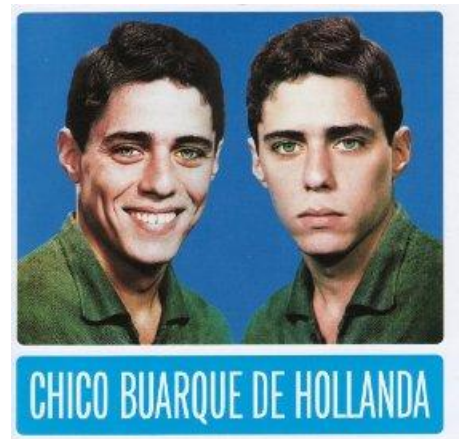

Figura 4: Capa do LP Chico Buarque de Holanda, de 1966.

Fonte: Discos do Brasil ${ }^{12}$

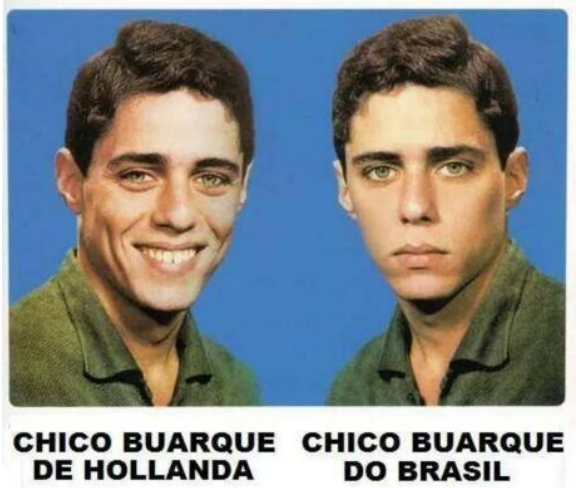

Figura 5: Meme "Chico Buarque Da Onda".

Fonte: Humorama ${ }^{13}$

12 Disponível em: <http://www.discosdobrasil.com.br/discosdobrasil/consulta/detalhe. php?Id_Disco=DIo0754>. Acesso em 15 jun. 2015.

13 Disponível em: <www.humorama.com.br/2014/o7/12/os-melhores-memes-da-derrota-dobrasil-para-a-holanda $>$. Acesso em 15 jun. 2015. 


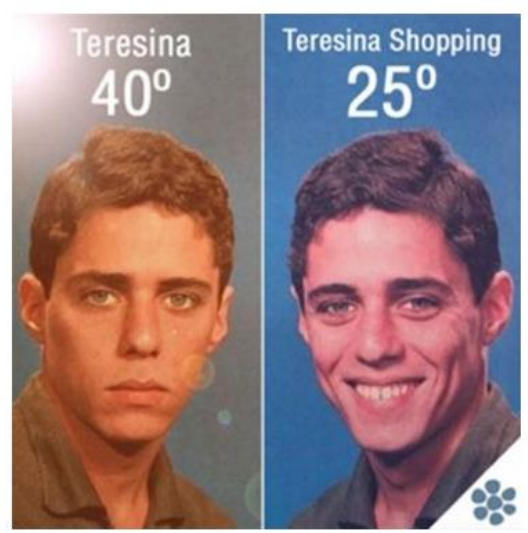

Figura 6: Meme "Chico Buarque da Onda” em campanha publicitária do Teresina Shopping (o shopping foi interpelado judicialmente pelo cantor e compositor por uso indevido de imagem).

Fonte: Meio e Mensagem ${ }^{14}$

Novamente, acontece a adaptação a diferentes contextos ou ambientes, desde uma derrota da seleção brasileira de futebol para a seleção holandesa na Copa do Mundo de 2014 (Figura 5), até o comercial de um shopping center em Teresina, PI (Figura 6). Neste último caso, a referência é feita ao conforto proporcionado pelo sistema de ar refrigerado do estabelecimento comercial. Mais uma vez, é possível destacar a longevidade, fecundidade e alcance do meme, devidas em grande parte à simplicidade de sua estrutura e à facilidade de edição.

\section{Considerações}

Como se pôde ver, os memes se oferecem como novas formas de produzir e difundir conteúdo. Atuam sobre o ambiente comunicacional, modificando-o ao proporcionarem aos sujeitos e grupos de interesse novos modos de apropriar-se da comunicação. Convivem com outras tecnologias, delas fazem uso e nelas se inserem. Recuperam imagens, conteúdos e traços das tecnologias mais tradicionais, ao mesmo tempo em que unem a elas elementos de uma outra linguagem, oferecendo modos de se adaptarem ao ambiente midiático da internet.

Facilmente modificáveis e adaptáveis a diferentes contextos, os memes imagéticos se inserem no ecossistema midiático como uma espécie nova e veloz. Ampliam possibilidades de comunicar, desafiam as demais espécies e a elas conferem certa obsolescência, mas também as recuperam naqueles aspectos que nelas se

14 Disponível em <http://www.meioemensagem.com.br/home/comunicacao/noticias/ 2015/02/04/ Chico-Buarque-processa-shopping-do-Piaui.html>. Acesso em 15 jun. 2015. 
mostram mais profícuos para os novos ambientes comunicacionais. Nesse processo de recuperação, nota-se como elemento importante o modo como os memes evocam memórias ligadas aos ambientes culturais nos quais os memes circulam, aspecto este presente na origem etimológica do próprio conceito de meme, no modo como foi concebido por Dawkins (2001).

Estamos em um contexto no qual diluem-se as barreiras entre os polos emissor e receptor. Um ambiente em mutação, no qual surgem e se disseminam novos processos de produção, circulação e recepção dos discursos (FAUSTO NETO, 2008). Particularmente nas redes sociais de internet, interessa aos participantes a possibilidade de produzirem, modificarem e compartilharem conteúdos com facilidade. A simplicidade e adaptabilidade dos memes vem atender a essa necessidade, mas também criam novas demandas para as outras espécies no ambiente em que se inserem. Pelo seu modo próprio de produção e reprodução, os memes podem provocar mudanças em outros dispositivos tecnológicos, outras espécies midiáticas com as quais se relacionam, como no exemplo da publicidade. Memes têm sido utilizados em diferentes contextos, que vão do puramente humorístico até o campo político e o religioso, e assim influem na maneira como se dá a comunicação nesses contextos.

Todas estas observações e muitas outras a serem realizadas remontam à ideia, já presente na ecologia da mídia, de que ao inserir-se uma espécie nova em um ecossistema, todas as demais sofrem o impacto e precisam se readaptar para sobreviver. Inserir a problemática dos memes na teoria ecológica abre múltiplas possibilidades para a sua compreensão e o estudo das mudanças que eles efetuam no ambiente comunicacional.

Essas características levantadas merecem, é claro, um exame mais aprofundado e uma análise abrangente. É possível e desejável, ainda, um aporte à dimensão discursiva desses memes como imagens que se propõem a variados efeitos de sentido nos diferentes contextos. Porém, nosso olhar aqui incidiu sobre parte do conceitual relacionado aos memes na especificidade de seu processo de produção e reprodução, com a intenção a que inicialmente nos propusemos, de evidenciar a 
importância de uma compreensão ecológica deste fenômeno. O meme como mais uma espécie no contexto amplo do ecossistema midiático.

\section{Referências}

BLAKMORE, Susan. The Power of the Meme Meme. In The Skeptic (EUA): 1997, vol. $5 \mathrm{n}^{\mathrm{o}}$ 2. Disponível em: <http://www.susanblackmore.co.uk/ Articles/sk97.html>. Acesso em 28 set. 2015.

BRAGA, José Luiz. Circuitos versus campos sociais. In: MATTOS, Maria Ângela; JANOTTI JUNIOR, Jeder; JACKS, Nilda (Org.) Mediação \& Midiatização. Salvador: EDUFBA, 2012, p. 31-52.

DAWKINS, Richard. O Gene Egoísta. Belo Horizonte: Itatiaia, 2001.

FAUSTO NETO, Antonio. Fragmentos de uma "analítica" da midiatização. Matrizes, São Paulo, vol.1, n.2, p. 89-105, abr. 2008. Disponível em: <http://www.matrizes.usp.br/index.php/matrizes/article/view/88>. Acesso em $22 \mathrm{Jul} 2015$.

GHISLENI, Taís Steffnello; BARICHELLO, Eugênia Mariano da Rocha. Ecologia das mídias nas redes sociais digitais: estendendo a Teoria Tetrádica de McLuhan ao estudo do Facebook. In RUBLESCKI, Anelise; BARICHELLO, Eugenia Mariano da Rocha (Orgs). Ecologia da Mídia. Santa Maria: Facos, 2013, p. 79-97.)

MCLUHAN, Marshal; MCLUHAN, Eric. Laws of media: the new Science. Toronto: University of Toronto Press, 1998.

RECUERO, Raquel da Cunha. Memes em weblogs: proposta de uma taxonomia. In Revista FAMECOS. Porto Alegre: $\mathrm{n}^{\mathrm{O}} 32$, abr./2007. Disponível em: <http://revistas. univerciencia.org/index.php/famecos/article/viewFile/ 1969/1785>. Acesso em 30 out. de 2014.

Redes sociais na internet. Porto-Alegre: Sulina, 2011.

RODRIGUES, Adriano Duarte. Experiência, modernidade e campo dos media. Biblioteca On Line de de Ciências da Comunicação. Portugal, 1999. Disponível em: <http://www.bocc.ubi.pt/pag/rodrigues-adriano-expcampmedia .pdf>. Acesso em 22 Jul 2015.

SCOLARI, Carlos A. Ecología de los medios. Mapa de un nicho teórico. In Quaderns del CAC, $\mathrm{n}^{\mathrm{O}}$ 34, Vol. XIII (1), Jun./2010. p. 17-25. Disponível em: $<$ http://www.cac.cat/pfw_files/cma/recerca/quaderns_cac/Q34_Scolari_ES.pd $\mathrm{f}>$. Acesso em 01 jun. de 2015 .

Más allá de McLuhan: Hacia una ecologia de los medios. In BARICHELLO, Eugenia Mariano da Rocha; RUBLESCKI, Anelise (orgs.). Ecologia da Mídia. Santa Maria: FACOS-UFSM, $2013 a$.

Media Evolution: Emergence, dominance, Survival, and Extinction in the Media Ecology. In International Journal of Communication. University of Southern California: $\mathrm{n}^{\circ}$ 7, 2013b, p. 1418-1441. 
Disponível em: <ijoc.org/index.php/ijoc/article/download/1919/936>. Acesso em 15 jun. 2015.

SOUZA, Humberto da Cunha Alves de. Memes(?) do Facebook: reflexões sobre esse fenômeno de comunicação da cultura ciber. In Revista Temática. João Pessoa: Universidade Federal da Paraíba - UFPB, Ano X, nº 07, Jul./2014. Disponível em: <http://periodicos.ufpb.br/ojs2/index.php/ tematica>. Acesso em 30 out. 2014.

TOLEDO, Gustavo Leal. Uma crítica à memética de Susan Blackmore. Revista de Filosofia. Curitiba: Aurora, v.25, $\mathrm{n}^{\mathrm{o}}$ 36, Jan.-Jun./2013. p. 179-195. Disponível em <www2.pucpr.br/reol/index.php/rf?dd99=pdf\&dd1=7770>. Acesso em 25 out. 2014.

VERÓN, Eliseo. Fragmentos de um tecido. São Leopoldo, RS, Editora Unisinos, 2005 .

VIZER, Eduardo; CARVALHO, Helenice. La metáfora ecológica en la era de la mediatización. In BARICHELLO, Eugenia Mariano da Rocha; RUBLESCKI, Anelise (orgs.). Ecologia da Mídia. Santa Maria: FACOS-UFSM, 2013. 